Original Research

\title{
Socio-demographic Determinants and The Family Ability to Care for Children with Avoidant Restrictive Food Intake Disorder (ARFID)
}

\author{
${ }^{1}$ Faculty of Public Health, Universitas Airlangga, East Java, Indonesia \\ 2 Faculty of Nursing, Universitas Airlangga, East Java, Indonesia \\ ${ }^{3}$ Faculty Medicine, Universitas Brawijaya Malang, East Java, Indonesia
}

Yoyok Beksi Prasetyo ${ }^{1}$, Nursalam Nursalam ${ }^{2}$, Rahmat Hargono ${ }^{1}$ and Ahsan Ahsan ${ }^{3}$

\begin{abstract}
Introduction: The ability of families to care for avoidant restrictive food intake disorder children is still low. There are only a few studies that examined the relationship between family factors and ability to care for children with avoidant restrictive food intake disorder. The purpose of this study was to identify the influence of socio-demographic factors on the ability of families to care for children with avoidant restrictive food intake disorder.
\end{abstract}

Methods: This study design was cross-sectional, with 245 participants. The sampling technique used was multistage sampling. Data were collected by using questionnaire. We then conducted an analysis of the univariate data using frequency distribution, while for the bivariate data, we used the chi-square technique. All of the data was processed using IBM SPSS 23.0 statistics.

Results: The results showed that the ability of care from the families (health promotion behavior) of children with avoidant restrictive food intake disorder was influenced by the socio-demographic factors, namely maternal age $(p=0.010)$, the number of children $(\mathrm{p}=0.047)$ and education $(\mathrm{p}=0.036)$.

Conclusion: Young mothers need appropriate guidance and direction through good health education. Good health education in young mothers can reduce the pressure faced by the mothers when caring for their children with avoidant restrictive food intake disorder. Health promotion behavior is influenced by maternal education and maternal age. Through good mother's education, the mother will be able to provide a good pattern of care to children who experience avoidant restrictive food intake disorder.

\section{ARTICLE HISTORY}

Received: April 10, 2019

Accepted: May 21, 2019

\section{KEYWORDS}

sociodemography; family ability; avoidant restrictive food intake disorder

\section{CONTACT}

Nursalam Nursalam $\triangle$ nursalam@fkp.ac.id $\ggg$ Faculty of Nursing, Universitas Airlangga, East Java, Indonesia

Cite this as: Prasetyo, Y.B, Nursalam, N, Hargono, R, and Ahsan, A. (2019). Socio-demographic Determinants and The Family Ability to Care for Children with Avoidant Restrictive Food Intake Disorder (ARFID). Jurnal Ners, 14(1), 1-9. doi:http://dx.doi.org/10.20473/in.v14i1.12735

\section{INTRODUCTION}

The ability of families to care for children with Avoidant Restrictive Food Intake Disorder (ARFID) is still low. The low family capacity means that there is a disruption of care from the family to care for children with ARFID. This is indicated by neglect and abuse in the family (Mairs and Nicholls, 2016). Neglect or maltreatment in children is indicated by the tension between parents and children between 13 - 82\% (Skovgaard Væver, Smith-Nielsen, and Lange, 2016). Skills in relation to providing a positive feeding style are a major problem (Blaine, Kachurak, Davison, Klabunde, \& Fisher, 2017; Kerzner et al., 2016; van der Horst \& Sleddens,
2017). Some of the problems related to this are forcing the food to run out at the age of infancy $(67.9 \%)$ and at the toddler stage (77.4\%), forcing food before the child feels hungry at the age of infancy $(26.3 \%)$ and at the toddler stage (53.9\%), giving sweet foods (ice cream, cakes, sweets) as much as at infancy (12.5\%) and at the toddler stage (52\%) and providing fast food as much as $8.9 \%$ at the age of infancy and $47.6 \%$ at the toddler stage (Baby et al., 2015). Forcing children to try new foods was $56.1 \%$ in infancy and $79.1 \%$ at the toddler stage (Baby et al., 2015).

Avoidant Restrictive Food Intake Disorder is a new term for describing infant and toddler feeding disorders with the following characteristics: refusing 
to eat, poor mealtime schedules, low eating skills that are not in accordance with the child's development stage (Davies et al., 2006), a lack of interest in eating, avoidance based on sensory food including the appearance of food, the smell and taste of the food, fear that occurs when eating such as dysphagia and a fear of swallowing food (Davies et al., 2006; Fisher et al., 2014; Kostro, Lerman, \& Attia, 2014; Nicely, Lane-Loney, Masciulli, Hollenbeak, \& Ornstein, 2014). The distinctive difference from other eating disorders is that in ARFID, there are also psychological disorders such as anxiety and a lack of good parenting (Strandjord et al., 2016; Zimmerman \& Fisher, 2017).

Children with ARFID were reported to be at $11 \%$ (Nakai et al., 2017), 12, 4\% (Fisher et al., 2014), $22.5 \%$ (Nicely et al., 2014) and 5\% - 23\% (Mairs \& Nicholls, 2016; Strandjord et al., 2016). Problems related to difficulty eating in children is largely determined by family factors, especially those of the mother or caregiver (Allen et al., 2015), where there is a dysfunctional mother and lacking in mother and child interaction (Goulding et al., 2014; Gueron-Sela, Atzaba-Poria, Meiri, \& Yerushalmi, 2011; Kröller \& Warschburger, 2009; Sacrato, Pellicciari, \& Franzoni, 2010; Squires, Lalanne, Murday, Simoglou, \& VaivreDouret, 2014), concerning the environmental and socio-cultural influences and any psychological tensions (Campbell \& Peebles, 2014; De Luca \& Napoletani, 2015; Strandjord, Sieke, Richmond, \& Rome, 2015). Parenting problems such as neglect and abuse are important factors for families with ARFID children (Mairs \& Nicholls, 2016). The prevalence of affection tension between parents was between $13-82 \%$ depending on the risk factors in the family such as neglected or maltreatment (Skovgaard Væver, Smith-Nielsen, \& Lange, 2016).

The problem of ARFID will have a serious impact on children's growth and development so that it can cause stunting and wasting. A serious problem is a disruption in the life cycle in the future (Ágh et al., 2015; Campbell \& Peebles, 2014; Segovia, 2015; Uher \& Rutter, 2012), such as stunting and wasting. Indonesia has a fluctuating trend and has increased against stunting in the period $2007-2010$. This is indicated by stunting data in Indonesia: $36.8 \%$ in 2007, 35.6\% in 2010 and 37.2\% in 2013 (Badan Penelitian dan Pengembangan Kesehatan, 2013; Kementerian Koordinator Bidang Kesejahteraan Rakyat, 2013).

Nutritional problems in children are influenced by the socio-demographic factors of the families, especially the mothers (Allen et al., 2015). The social demographic factors that cause the children to experience difficulty eating are dysfunctional mother and child interactions (Allen et al., 2015; Goulding et al., 2014; Gueron-Sela et al., 2011; Kröller \& Warschburger, 2009; Sacrato et al., 2010), environmental and socio-cultural influences and psychological tensions (Campbell \& Peebles, 2014; De Luca \& Napoletani, 2015). The education level of the mother determines the nutritional status of the child (Habibi, Zahra, Aguenaou, \& Doukkali, 2018). The good education of the mother will have an impact on the pattern of giving good food to the child (Do, Eriksson, Tran, Petzold, \& Ascher, 2015). Paying attention to social and demographic characteristics is an important factor for improving the child's nutritional status (Holbrook, White, Heyman, \& Wojcicki, 2013).

There is still very little research related to ARFID in Indonesia. This study had the main objective of analyzing determinant factors of socio-demography in relation to the ability of families to care for children with ARFID. The secondary objective was to compare the socio-demographic characteristics of the mothers and the nutritional status of the children, namely between mothers who worked and mothers who did not work and the ability of their families to care for children with ARFID. The purpose of this study was to identify the influence of socio-demographic factors on the ability of families to care for children with ARFID.

\section{MATERIALS AND METHODS}

The research location was in Malang Regency. Malang Regency has 69 integrated health posts divided into six Regional Coordinators (Korwil); Singosari, Tumpang, Turen, Pujon, Pagak, and Bantur. The Singosari Regional Office was determined to be a population area because of the presence of nutritional problems for infants, easy access, ease of transportation and relatively cheaper costs. The Singosari Regional Office included Pakis, Karangploso, Singosari Health Center, Ardimulyo, and Lawang Community Health Center (there were five community health centers).

The study design was cross-sectional. The sample size is determined using the rule of thumb in Structural Equation Modeling (SEM), which is the number of parameters estimated multiplied by 5 or 10 (Azman, 2017). There are 10 parameters so that the sample size is $10 \times 10=100$ participants (minimal). In this study, a sample of 245 participants was used. This research was conducted from December 2018 - March 2019. The sampling technique was multistage sampling, namely gradual sampling (Taherdoost, 2018). Phase one determines the puskesmas then in stage two chooses the posyandu ( $n=229)$. In this study, $20 \%$ of posyandu ( $\mathrm{n}=46$ ) were determined by simple random sampling. In the third stage, families with ARFID children were determined with a sample of 245 families with ARFID children. Participant inclusion criteria included children experiencing ARFID $(<5$ years), children who were not ill with chronic diseases, not experiencing congenital defects on the eating path.

The data collection was assisted by eight research assistants. The data collection was carried out through a survey using a questionnaire, both in community health centers and in the homes of 
residents. The demographic characteristics questionnaire was developed by the researchers. The socio-demographic characteristics focused on the number of children, the age of the child, the mother's age, the mother's level of education and family income. The nutritional status of the children was determined by the anthropometry measurement, which refers to the WHO standard in 2005. The ability of families to care for children with ARFID have indicators of ability related to managing eating disorders and the ability to take health promotion actions (good category score $=\mathrm{X}>$ mean + $\mathrm{SD}$; enough $=$ mean-SD $\leq \mathrm{X} \leq$ mean $+\mathrm{SD}$; less $=\mathrm{X}$ $<$ mean - SD).

Independent variables are maternal and child demographic factors while the dependent variable is the family's ability to care for ARFID. Family ability consists of two sub-variables, namely the ability to manage eating disorders and the ability to show promotive behavior. The eating disorder management questionnaire consists of 9 items of statements with indicators: 1 ) cooperation with the health team, 2) cooperation with family members, 3) stepping positive relationships, 4) monitoring vital sign, 5) monitoring fluid output intakes, 6) setting appropriate expectations, 7) use behavior modification, 8) discuss with the health team, 9) take responsibility. Using a 5 point Likert scale (1: never, 2: rarely, 3: sometimes, 4: often, 5: always). The questionnaire has been tested for validity and reliability. Validity test results show valid with a value of $>0.4$ and the reliability value of managing eating disorder (Cronbach's alpha $=0.888$ ). The promotive behavior questionnaire consisted of 11 items of questions, with indicators: 1) asking appropriate questions, 2) completing assignments, 3) showing early examinations, 4) contacting health personnel, 5) showing ability, 6) explaining behavior change strategies, 7) obey strategy, 8) show healthy behavior, 9) seek health information, 10) explain strategies for maximizing health, 11) explain individual development strategies. Using a 5 point Likert scale (1: never, 2: rarely, 3: sometimes, 4: often, 5: always). Test the validity of all question items $>0.4$ and reliability values (Cronbach's alpha $=$ 0.830 ). The analysis of the univariate data used frequency distribution, while for bivariate data, we used the chi-square technique. All of the data was processed using IBM SPSS 23.0 statistics.

This research was carried out with the approval of the Declaration of Helsinki. Ethical approval as granted by the research ethics committee of the Faculty of Public Health, Airlangga University number 333- KEPK. All participants filled an informed consent form with their signature. The privacy and confidentiality of the data were highly guaranteed.

\section{RESULTS}

Table 1 shows that the average maternal age between working and non-working (W / NW) groups was 30 years old. The average age of children with ARFID between the two groups - W / NW = 2.25 / 2.05 years (toddler age). The average number of $\mathrm{W}$ / NW children was the same (2/2). The sex of the children was mostly female both in group W / NW (60\% / 53.7\%). The income per month between 2 groups also did not have a significant difference with the majority of the income falling between $1-2$ million / month. Demographic factors for maternal age, age of children, number of children, the gender of the child, income per month, no significant differences were found between groups of working mothers and non-working ( $p$ value $>0.05$ ). The mother's education in the working group was higher than in the group of mothers who did not work. This can be seen from the highest education category, namely college $(\mathrm{W} / \mathrm{NW}=23.6 \% / 9.5 \%$; $\mathrm{p}=0.019$ ).

The anthropometric characteristics include height $(\mathrm{H})$ and body weight $(\mathrm{W})$ with the Categories of W /U. H/ U. W / H are presented in Table 2. The mean $\mathrm{W}$ of children between the two groups was W / $\mathrm{NW}=11.9 / 11.2 \mathrm{~kg}$. The average $\mathrm{H}$ of the children between the two groups was N / NW = 86.9 / 84.4 $\mathrm{cm}$. The nutritional status of the children based on $\mathrm{W}$ / $U$ in both groups was lacking and they had a very poor nutritional status $(\mathrm{W}=7.3 \%$ and $1.8 \%$; $\mathrm{NW}=$ $18.4 \%$ and $3.2 \%$ ). The nutritional status based on $\mathrm{H}$ / U also contained stunting conditions in both groups. This stunting condition can be seen from the presence of short and very short categories (W= $10.9 \%$ and 16.4\%; $\mathrm{NW}=16.8 \%$ and $21.6 \%$ ). Nutritional status based on W / H involved a wasting condition in both groups. This wasting condition can be seen from the thin and very thin categories ( $\mathrm{W}=$ $5.5 \%$ and $3.6 \%$; $\mathrm{NW}=10.5 \%$ and $2.6 \%$ ). Table $3 \mathrm{a}$ shows that the family's ability to treat (manage eating disorder) children with ARFID is influenced by sociodemographic factors: maternal age $(\mathrm{p}=$ $0.006)$ and a number of children ( $p=0.001)$.

Table 3a shows most of the family's ability to manage eating disorders in the category was quite good in the group of mothers who were under 30 years old $(71.9 \%)$ or in the group of women who were over 30 years old (68.4\%). The largest percentage of the family's ability to manage eating disorders, including the poor categories, was based on socio-demographics such as maternal age $(\geq 31$ years: $22.2 \%$ ), the number of children (3-4 children: $34.9 \%$ ), income ( $<1$ million: $23.2 \%)$, education (basic: 22\%). and work (working: 20\%). 


\section{Y. B. PRASETYO ET AL.}

Table 1. Socio-demographic characteristics between the Working Mother (W) and Non-Working (NW) Groups

\begin{tabular}{|c|c|c|c|c|}
\hline Characteristics & $\begin{array}{c}\text { W n (\%) or M (SD) } \\
n=55\end{array}$ & $\begin{array}{c}\text { NW n (\%) or M (SD) } \\
n=190\end{array}$ & $\begin{array}{c}\text { Total n (\%) or M (SD) } \\
n=245\end{array}$ & p value ${ }^{*}$ \\
\hline Mother's age & $30(6)$ & $30(6)$ & $30(6)$ & 0.905 \\
\hline Child's age & $2.28(1.24)$ & $2.05(1.07)$ & $2.10(1.11)$ & 0.183 \\
\hline Number of children & $2(1)$ & $2(1)$ & $2(1)$ & 0.400 \\
\hline \multicolumn{5}{|l|}{ Gendera } \\
\hline Man & $22(40)$ & $88(46.3)$ & $110(44.9)$ & 0.407 \\
\hline Women & $33(60)$ & $102(53.7)$ & $135(55.1)$ & \\
\hline \multicolumn{5}{|l|}{ Income monthb } \\
\hline Above 2 million & $18(32.7)$ & $45(23.7)$ & $63(25.7)$ & 0.397 \\
\hline $1-2$ Million & $26(47.3)$ & $100(52.6)$ & $126(51.4)$ & \\
\hline Under 1 million & $11(20)$ & 45 (23.7) & $56(22.9)$ & \\
\hline \multicolumn{5}{|l|}{ Educationc } \\
\hline College & $13(23.6)$ & $18(9.5)$ & $31(12.7)$ & 0.019 \\
\hline High school & $13(23.6)$ & $76(40)$ & $89(36.3)$ & \\
\hline Junior high school & $17(30.9)$ & $58(30.5)$ & $75(30.6)$ & \\
\hline Elementary school & $12(21.8)$ & $38(20)$ & $50(20.4)$ & \\
\hline
\end{tabular}

Note W (Works). NW (Not Working). M (mean). SD (standard deviation)

a Gender of child

b Family income in 1 month

${ }^{\mathrm{c}}$ Mother's education level

* Level of significance is 0.05

Table 2. Characteristics of the Anthropometry of Children between Working and Non-Working Mothers

\begin{tabular}{|c|c|c|c|c|}
\hline Characteristics & $\begin{array}{c}W n(\%) \text { or M(SD) } \\
n=55\end{array}$ & $\begin{array}{c}\text { NW n(\%) or M(SD) } \\
n=190\end{array}$ & $\begin{array}{c}\text { Total n(\%) or M(SD) } \\
n=245\end{array}$ & p value ${ }^{*}$ \\
\hline Weight $(\mathrm{kg})^{\mathrm{a}}$ & $11.9(2.8)$ & $11.2(2.7)$ & $11.4(2.7)$ & 0.119 \\
\hline Height $(\mathrm{cm})^{\mathrm{a}}$ & $86.9(10.3)$ & $84.4(10)$ & $85(10.1)$ & 0.109 \\
\hline \multicolumn{5}{|l|}{ Weight/Ub } \\
\hline Overweight & $0(0)$ & $2(1.1)$ & $2(0.8)$ & 0.161 \\
\hline Normal & $50(90.9)$ & $147(77.4)$ & $197(80.4)$ & \\
\hline Underweight & $4(7.3)$ & 35 (18.4) & 39 (15.9) & \\
\hline Very underweight & $1(1.8)$ & $6(3.2)$ & $7(2.9)$ & \\
\hline \multicolumn{5}{|l|}{ Height/Ub } \\
\hline Tall & $2(3.6)$ & $6(3.2)$ & $8(3.3)$ & 0.500 \\
\hline Normal & 38 (69.1) & $111(58.4)$ & $149(60.8)$ & \\
\hline Short & $6(10.9)$ & $32(16.8)$ & $38(15.5)$ & \\
\hline Very short & 9 (16.4) & $41(21.6)$ & $50(20.4)$ & \\
\hline \multicolumn{5}{|l|}{ Weight//Hb } \\
\hline Overweight & $3(5.5)$ & $24(12.6)$ & $27(11)$ & 0.260 \\
\hline Normal & $47(85.5)$ & $141(74.2)$ & $188(76.7)$ & \\
\hline underweight & $3(5.5)$ & $20(10.5)$ & $23(9.4)$ & \\
\hline Very underweight & $2(3.6)$ & $5(2.6)$ & $7(2.9)$ & \\
\hline
\end{tabular}

Note: N (Works). NW (Not Working). M (mean). SD (standard deviation)

a $\mathrm{W}$ and $\mathrm{H}$ data obtained from a notebook in the integrated health post

$\mathrm{b}$ The determination of the category was done through the Z-score value

* level of significance is 0.05

Table $3 b$ shows that the caring ability of the families (health promotion behavior) of children with ARFID is influenced by socio-demographic factors, namely maternal age $(p=0.010)$, the number of children ( $p=0.047)$ and education $(p=0.036)$. Most of the family's ability to behave in health promotion was quite good in the group of women who were under 30 years of age $(74.2 \%)$ or in the group of women who were over 30 years old (68.4\%). Health promotion behavior in the good category is based on socio-demography with a higher percentage in maternal age $\leq 30$ years:
$17.2 \%)$, the number of children (1-2 children: $15.9 \%$ ), the equal income between those who earn $>$ 2 million and the groups that earn 1-2 million $(14.3 \%)$, those with an education (middle-high: 14.9\%) and work (not working: 14.2\%).

\section{DISCUSSION}

The average age of the mothers was in the productive age with the ability to manage eating disorders and health promotion behavior; this differed between the groups of mothers under or equal to 30 years old. Mothers who are of a younger 
Table 3a. Socio-demographics and The Family's Ability to Manage Their Child's Eating Disorder

\begin{tabular}{|c|c|c|c|c|}
\hline \multirow{2}{*}{ Characteristic } & \multicolumn{3}{|c|}{ Ability to Manage an Eating Disorder } & \multirow[b]{2}{*}{$p$-value } \\
\hline & Less n (\%) & Enough n (\%) & Well n (\%) & \\
\hline \multicolumn{5}{|l|}{ Mother age } \\
\hline$\leq 30$ years & $12(9.4)$ & $92(71.9)$ & $24(18.8)$ & 0.006 \\
\hline$\geq 31$ years & $26(22.2)$ & $80(68.4)$ & $11(9.4)$ & \\
\hline \multicolumn{5}{|l|}{ Number of children } \\
\hline $1-2$ child & $23(11.4)$ & $145(72.1)$ & $33(16.4)$ & 0.001 \\
\hline $3-4$ child & $15(34.9)$ & $26(60.5)$ & $2(4.7)$ & \\
\hline \multicolumn{5}{|l|}{ Income } \\
\hline$<1$ millions & $13(23.2)$ & $36(64.3)$ & $7(12.5)$ & 0.255 \\
\hline $1-2$ millions & $19(15.1)$ & $91(72.2)$ & $16(12.7)$ & \\
\hline$>2$ millions & $6(9.5)$ & $45(71.4)$ & $12(19)$ & \\
\hline \multicolumn{5}{|l|}{ Education } \\
\hline Elementary school & $11(22)$ & $34(68)$ & $5(10)$ & 0.278 \\
\hline Midlle - College & $27(13.8)$ & $138(70.8)$ & $30(15.4)$ & \\
\hline \multicolumn{5}{|l|}{ Job } \\
\hline Working & $11(20)$ & $37(67.3)$ & $7(12.7)$ & 0.569 \\
\hline No Working & $27(14.2)$ & $135(71.1)$ & $28(14.7)$ & \\
\hline
\end{tabular}

Table 3b. Socio-demographics and the Family Caring Ability (Health Promotion Behavior)

\begin{tabular}{|c|c|c|c|c|}
\hline \multirow[b]{2}{*}{ Characteristic } & \multicolumn{3}{|c|}{ Ability to Show Promotive Behavior } & \multirow[b]{2}{*}{$p$-value } \\
\hline & Less n (\%) & Enough n (\%) & Well n (\%) & \\
\hline \multicolumn{5}{|l|}{ Mother age } \\
\hline$\leq 30$ years & $11(8.6)$ & $95(74.2)$ & $22(17.2)$ & 0.010 \\
\hline$\geq 31$ years & $25(21.4)$ & $80(68.4)$ & $12(10.3)$ & \\
\hline \multicolumn{5}{|l|}{ Number of children } \\
\hline $1-2$ child & $25(12.4)$ & $144(71.6)$ & $32(15.9)$ & 0.047 \\
\hline $3-4$ child & $10(23.3)$ & $31(72.1)$ & $2(4.7)$ & \\
\hline \multicolumn{5}{|l|}{ Income } \\
\hline$<1$ millions & $15(26.8)$ & $34(60.7)$ & 7 (12.5) & 0.055 \\
\hline $1-2$ millions & $16(12.7)$ & $92(73)$ & $18(14.3)$ & \\
\hline$>2$ millions & $5(7.9)$ & $49(77.8)$ & $9(14.3)$ & \\
\hline \multicolumn{5}{|l|}{ Education } \\
\hline Elementary school & $13(26)$ & $32(64)$ & $5(10)$ & 0.036 \\
\hline Middle - High & $23(11.8)$ & 143 (73.3) & $29(14.9)$ & \\
\hline \multicolumn{5}{|l|}{ Job } \\
\hline Working & 7 (12.7) & $41(74.5)$ & 7 (12.7) & 0.839 \\
\hline No Working & $29(15.3)$ & $134(70.5)$ & $27(14.2)$ & \\
\hline
\end{tabular}

age have the ability to treat eating disorders better than the mothers over the age of 31 years old. Relatively younger mothers will learn to recognize themselves and learn to be responsible for their children if they experience ARFID. Responsible learning is shown through affection, responsiveness, and responsibility when it comes to caring for their child (Dlamini, 2016). This sense of responsiveness is indicated by the acceptance of the signs/signals that the child shows. They need to interpret signals well and provide the appropriate response as indicated by voice, facial expressions and touch (Esposito, Manian, Truzzi, \& Bornstein, 2017; Lavallée, Aita, Bourbonnais, \& De Clifford-Faugère, 2017). Sensitive responses from the parents include accuracy, consistency and the appropriate response from the parents concerning the signs of affection that come from the child (Troutman, 2015). Responsiveness is a dimension related to parental responsiveness in terms of guiding a child's personality regarding assertiveness, self-regulation and the fulfillment of special needs (Kasy, 2017). In addition to the above factors, relatively younger mothers who live within large families such as where grandparents are present will get full support from their families (financial, emotional and care support) (Easterbrooks, Chaudhuri, Bartlett, \& Copeman, 2011). Family support is very much needed in childcare to provide protection and direction (Cismaru \& Le Pioufle, 2016).

Children experience ARFID on average in the toddler age group. ARFID symptoms at the age of infancy and in the toddler stage include refusing to eat, a bad meal schedule and low eating skills (Davies et al., 2006). Children aged 6 months - 3 years will experience infantile anorexia which is characterized by rejecting a number of foods, the inability to control hunger and fullness, environmental disturbances and experiencing growth and development disorders. This is because toddler-age children experience a transition to the habit of being fed themselves. New dynamics also 
occur between the children and their caregivers. The child learns to put food in their own mouth. The children learn to feel the sensation of hunger and fullness while the caregivers always try to keep on forcing the food. The impact is that their children will feel depressed while eating (Merwin, Advisor, \& Gray, 2010)

The education level of the mothers in the working mother's group was higher. Mothers who have a higher education level will have the chance to get a better job position. Better work will help the family financially when it comes to providing facilities that support children's growth and development (Putri \& Gutama, 2018). The challenge for mothers when it comes to working on their parenting is to provide warmth, attention, and care for their children. The mothers are able to provide attachment to their children on the sidelines of their busy life so then the closeness is still intertwined with the interconnection of positive feelings that will have a positive impact on the child's development (Dewi, 2016). Good communication can create a harmonious family atmosphere, such as being open to each other and having trust. This warm interaction will have an impact on children's health. Mothers who have good interactions with their children, mothers will be able to provide good care shown by being able to manage their children's health and be able to carry out health promotion actions (Panico, 2012).

Working mothers will also get additional information. The knowledge and networking are better than those of the mothers who don't work. This will increase the confidence of their individual beliefs when dealing with children's problems related to ARFID. Confidence is the basis that determines someone as being able to take preventive action against diseases and health promotion activities (Akey, Rintamaki, \& Kane, 2013). This explains why someone changes or maintains specific health behaviors (Akey et al., 2013; James, Pobee, Oxidine, Brown, \& Joshi, 2012; Poortaghi et al., 2015) and it also explains why someone can fail to participate in activities aimed at detecting or preventing disease (Borowski \& Tambling, 2015). This helps to predict if someone will take actions in relation to prevention, screening and controlling illness conditions (Glanz, Rimer, \& Viswanath, 2008).

Children with ARFID experience stunting and wasting (Campbell \& Peebles, 2014). Stunting and wasting problems occur due to the failure to meet their appropriate nutritional needs and/or energy requirements (Katzman, Stevens, \& Norris, 2014). Next, it will cause one or more signs of significant weight loss, caused by a lack of nutrition. Children are very dependent on nutrition, oral supplements and the presence of psychosocial functions (Berlin, Davies, Silverman, \& Rudolph, 2011; Sharp, Volkert, Scahill, McCracken, \& McElhanon, 2017). This causes physical health problems and has an impact on social, emotional and cognitive development (Goudet et al., 2018). If it continues until adolescence, then there will be a disruption of identity and self-esteem (Mairs \& Nicholls, 2016). Impaired identity and selfesteem are associated with a body shape that is too thin, giving rise to shame and insecurity (King, Urbach, \& Stewart, 2015).

Having a smaller number of children, between 12 children, correlates associated with the better ability to manage eating disorders and the ability to conduct better health promotion behaviors. This is when compared with families that have 3 to 4 children. Mothers with fewer children will be able to maintain warmer mother-child interactions. This is due to the availability of sufficient time to interact. This warm interaction will affect children's health. Mothers who have good interactions with their children will be able to provide good care as shown by being able to manage the health of their children and being able to take health promotion actions (Panico, 2012). The ability of mothers to take health promotion actions is determined by the mother's education. Maternal education is linear to the ability of the mothers of health promotion behavior. The mother's education is one of the factors that determine the success of the parenting patterns present when feeding their children(Do et al., 2015; Goulding et al., 2014). In contrast, low maternal education results in poor health promotion behavior (Mulyani, 2016).

\section{CONCLUSION}

The ability to care for children with avoidant restrictive food intake disorder children is impacted on by the maternal socio-demographic factors. Eating disorders are regulated by maternal age. Young mothers can get the right guidance and direction through good health education when caring for children with avoidant restrictive food intake disorder children. Health promotion behavior is influenced by maternal education and maternal age. Through good mother's education, the mother will be able to provide a good pattern of care to children who have avoidant restrictive food intake, disorder children. The quality of the mother's interaction and will be a very important part. Increasing mother and child interaction is one of the keys to the implementation of nursing to provide nursing care to children who experience ARFID.

\section{REFERENCES}

Ágh, T., Kovács, G., Pawaskar, M., Supina, D., Inotai, A., \& Vokó, Z. (2015). Epidemiology, health-related quality of life and economic burden of binge eating disorder: a systematic literature review. Eating and weight disorders: EWD, 20(1), 1-12. https://doi.org/10.1007/s40519-014-0173-9

Akey, J. E., Rintamaki, L. S., \& Kane, T. L. (2013). Health Belief Model deterrents of social support seeking among people coping with eating disorders. Journal of Affective Disorders, 145(2), 
246-252.

https://doi.org/10.1016/j.jad.2012.04.045

Allen, S. L., Smith, I. M., Duku, E., Vaillancourt, T., Szatmari, P., Bryson, S., ... Zwaigenbaum, L. (2015). Behavioral pediatrics feeding assessment scale in young children with autism spectrum disorder: Psychometrics and associations with child and parent variables. Journal of pediatric psychology, 40(6), 581-590.

Azman, A. H. N. (2017). Structural Equation Modeling (SEM): Confirmatory Factor Analysis (CFA), 72(1), $1-11$. https://doi.org/10.13140/RG.2.2.25615.38565

Baby, C., Sacc, N. A. P., Blaine, R. E., Davison, K. K., Hesketh, K., Taveras, E. M., ... Neelon, S. E. B. (2015). Child Care Provider Adherence to Infant and Toddler Feeding Recommendations: Findings from the Baby Nutrition and Physical Activity Self-Assessment for Child Care (Baby NAP SACC) Study. Childhood obesity Journal, 11(3). https://doi.org/10.1089/chi.2014.0099

Badan Penelitian dan Pengembangan Kesehatan. (2013). Riset Kesehatan Dasar (RISKESDAS) 2013. Laporan Nasional 2013, 1-384. https://doi.org/1 Desember 2013

Berlin, K. S., Davies, W. H., Silverman, A. H., \& Rudolph, C. D. (2011). Assessing family-based feeding strategies, strengths, and mealtime structure with the feeding strategies questionnaire. Journal of Pediatric Psychology, 36(5), https://doi.org/10.1093/jpepsy/jsp107

Blaine, R. E., Kachurak, A., Davison, K. K., Klabunde, R., \& Fisher, J. O. (2017). Food parenting and child snacking: a systematic review. International Journal of Behavioral Nutrition and Physical Activity, 14(146), 1-23. https://doi.org/10.1186/s12966-017-0593-9

Borowski, S. C., \& Tambling, R. B. (2015). Applying the Health Belief Model to Young Individuals' Beliefs and Preferences About Premarital Counseling, 23(4), 417-426. https://doi.org/10.1177/1066480715602221

Campbell, K., \& Peebles, R. (2014). Eating Disorders in Children and Adolescents: State of the Art Review. Pediatrics, 134(3), 582-592. https://doi.org/10.1542/peds.2014-0194

Cismaru, M., \& Le Pioufle, A. (2016). Helping Families Affected by Depression: Incorporating Prosocial and Caregiving Literature. International Business Research, 9(12), 23. https://doi.org/10.5539/ibr.v9n12p23

Davies, W. H., Satter, E., Berlin, K. S., Sato, A. F., Silverman, A. H., Fischer, E. a, ... Rudolph, C. D. (2006). Reconceptualizing Feeding and Feeding Disorders in Interpersonal Context: The Case for a Relational Disorder. Journal of Family Psychology, 20(3), 409-417. https://doi.org/10.1037/0893-3200.20.3.409

De Luca, G., \& Napoletani, M. (2015). Premonitory symptoms of Feeding and Eating Disorders in pediatric age. Italian Journal of Pediatrics, 41(Suppl 2), A25. https://doi.org/10.1186/18247288-41-S2-A25

Dewi, E. M. P. (2016). Pengasuhan Ibu Berkarir dan Internalisasi Nilai Karir pada Remaja. Jurnal Ilmiah Psikologi Terapan, 3(1), 165-183.

Dlamini, N. (2016). Teenage mothers 'experiences of motherhood- schooling, stigma and learned responsibility: a case study of teenage mothers of school going age in a peri-urban area in Kwa-Zulu Natal. Stellenbosch University.

Do, L. M., Eriksson, B., Tran, T. K., Petzold, M., \& Ascher, H. (2015). Feeding of preschool children in Vietnam: A study of parents' practices and associated factors. BMC Nutrition, 1(1), 16.

Easterbrooks, M. A., Chaudhuri, J. H., Bartlett, J. D., \& Copeman, A. (2011). Resilience in parenting among young mothers: Family and ecological risks and opportunities. Children and Youth Services Review, 33(1), 42-50.

Esposito, G., Manian, N., Truzzi, A., \& Bornstein, M. H. (2017). Response to infant cry in clinically depressed and non-depressed mothers. PLoS ONE, 12(1), 1-16. https://doi.org/10.1371/journal.pone.0169066

Fisher, M. M., Rosen, D. S., Ornstein, R. M., Mammel, K. A., Katzman, D. K., Rome, E. S., ... Walsh, B. T. (2014). Characteristics of avoidant/restrictive food intake disorder in children and adolescents: a "new disorder" in DSM-5. Journal of Adolescent Health, 55(1), 49-52.

Glanz, K., Rimer, B. K., \& Viswanath, K. (2008). Health behavior and health education: theory, research, and practice. John Wiley \& Sons.

Goudet, S., Griffiths, P. L., Wainaina, C. W., Macharia, T. N., Wekesah, F. M., Wanjohi, M., ... KimaniMurage, E. (2018). Social value of a nutritional counselling and support program for breastfeeding in urban poor settings, Nairobi. BMC public health, 18(1), 424.

Goulding, A. N., Rosenblum, K. L., Miller, A. L., Peterson, K. E., Chen, Y.-P., Kaciroti, N., \& Lumeng, J. C. (2014). Associations between maternal depressive symptoms and child feeding practices in a cross-sectional study of low-income mothers and their young children. International Journal of Behavioral Nutrition and Physical Activity, 11(1), 75.

Gueron-Sela, N., Atzaba-Poria, N., Meiri, G., \& Yerushalmi, B. (2011). Maternal worries about child underweight mediate and moderate the relationship between child feeding disorders and mother-child feeding interactions. Journal of Pediatric Psychology, 36(7), 827-836. https://doi.org/10.1093/jpepsy/jsr001

Habibi, M., Zahra, F., Aguenaou, H., \& Doukkali, L. (2018). International Journal of Pediatrics and The impact of maternal socio-demographic characteristics on breastfeeding knowledge and practices: An experience from. International Journal of Pediatrics and Adolescent Medicine, 
$5(2)$,

$39-48$.

https://doi.org/10.1016/j.ijpam.2018.01.003

Holbrook, K. E., White, M. C., Heyman, M. B., \& Wojcicki, J. M. (2013). Maternal sociodemographic characteristics and the use of the Iowa Infant Attitude Feeding Scale to describe breastfeeding initiation and duration in a population of urban, Latina mothers: a prospective cohort study. International breastfeeding journal, 8(1), 1-14. https://doi.org/10.1186/1746-4358-8-7

James, D. C. S., Pobee, J. W., Oxidine, D., Brown, L., \& Joshi, G. (2012). Using the Health Belief Model to Develop Culturally Appropriate WeightManagement Materials for African-American Women. Journal of the Academy of Nutrition and Dietetics, 112(5), 664-670. https://doi.org/10.1016/j.jand.2012.02.003

Kasy, S. (2017). Pengasuhan Anak pada Orangtua yang Menikah Usia Dini di Kabupaten Konawe Selatan Provinsi Sulawesi Tenggara. Program Studi Psikologi FPSI-UKSW.

Katzman, D. K., Stevens, K., \& Norris, M. (2014). Redefining feeding and eating disorders : What is avoidant / restrictive food intake disorder? Paediatrics Child Health, 19(8), 445-446. Diambil dari

http://www.cpsp.cps.ca/uploads/publications/H ighlights-avoidant-restrictive-food-intakedisorder.pdf

Kementerian Koordinator Bidang Kesejahteraan Rakyat. (2013). Kerangka Kebijakan Gerakan Nasional Percepatan Perbaikan Gizi dalam Rangka Seribu Hari Pertama Kehidupan (Gerakan 1000 HPK), 71.

Kerzner, B., Milano, K., MacLean, W. C., Berall, G., Stuart, S., \& Chatoor, I. (2016). A practical approach to classifying and managing feeding difficulties. Pediatrics, 135(2), 70. https://doi.org/10.1542/peds.2014-1630

King, L. A., Urbach, J. R., \& Stewart, K. E. (2015). Illness anxiety and avoidant/restrictive food intake disorder: Cognitive-behavioral conceptualization and treatment. Eating Behaviors, 19, 106-109. https://doi.org/10.1016/j.eatbeh.2015.05.010

Kostro, K., Lerman, J. B., \& Attia, E. (2014). The current status of suicide and self-injury in eating disorders: a narrative review. Journal of eating disorders, $2,219$. https://doi.org/10.1186/s40337-014-0019-x

Kröller, K., \& Warschburger, P. (2009). Maternal feeding strategies and child's food intake: considering weight and demographic influences using structural equation modeling. The international journal of behavioral nutrition and $\begin{array}{lll}\text { physical activity, } & 6,\end{array}$ https://doi.org/10.1186/1479-5868-6-78

Lavallée, A., Aita, M., Bourbonnais, A., \& De CliffordFaugère, G. (2017). Effectiveness of early interventions for parental sensitivity following preterm birth: a systematic review protocol. $\begin{array}{lll}\text { Systematic } & \text { reviews, } 6(1),\end{array}$ https://doi.org/10.1186/s13643-017-0459-x

Mairs, R., \& Nicholls, D. (2016). Assessment and treatment of eating disorders in children and adolescents, 1168-1175. https://doi.org/10.1136/archdischild-2015309481

Merwin, S., Advisor, C., \& Gray, J. (2010). Feeding Disorders of Infants and Toddlers: A Follow-up to the Treatment of Infantile Anorexia.

Mulyani, S. (2016). Pengaruh konseling menyusui terhadap sikap menyusui ibu postpartum yang dirawat. Jambi Medical Journal, 4(1), 28-38.

Nakai, Y., Nin, K., Noma, S., Hamagaki, S., Takagi, R., Teramukai, S., \& Wonderlich, S. A. (2017). Clinical presentation and outcome of avoidant/restrictive food intake disorder in a Japanese sample. Eating Behaviors, 24, 49-53. https://doi.org/10.1016/j.eatbeh.2016.12.004

Nicely, T. A., Lane-Loney, S., Masciulli, E., Hollenbeak, C. S., \& Ornstein, R. M. (2014). Prevalence and characteristics of avoidant/ restrictive food intake disorder in a cohort of young patients in day treatment for eating disorders. Journal of Eating Disorders, $2(2$ SUPPL. 1), S38. https://doi.org/10.1016/j.jadohealth.2012.10.09 2

Panico, L. (2012). Family structure and child health. University College London.

Poortaghi, S., Raiesifar, A., Bozorgzad, P., Golzari, S. E. J., Parvizy, S., \& Rafii, F. (2015). Evolutionary concept analysis of health seeking behavior in nursing: a systematic review. BMC health services research, 15(1), 523. https://doi.org/10.1186/s12913-015-1181-9

Putri, R. A., \& Gutama, T. A. (2018). Strategi pasangan suami istri dalam menjaga keharmonisan keluarga wanita karir (studi kasus wanita karir di Desa Pucangan, Kelurahan Pucangan, Kecamatan Kartasura). Journal of Development and Social Change, 1(1), 1-8. Diambil dari https: //jurnal.uns.ac.id/jodasc

Sacrato, L., Pellicciari, A., \& Franzoni, E. (2010). Emergent factors in eating disorders in childhood and preadolescence. Italian journal of pediatrics, 36, 49. https://doi.org/10.1186/1824-7288-3649

Segovia, M. J. G. (2015). Psychological and psychological impairment in preschoolers with selective eating. Acta Pediatrica Espanola, 73(9), 240. https://doi.org/10.1542/peds.2014-2386

Sharp, W. G., Volkert, V. M., Scahill, L., McCracken, C. E., \& McElhanon, B. (2017). A systematic review and meta-analysis of intensive multidisciplinary intervention for pediatric feeding disorders: how standard is the standard of care? The Journal of pediatrics, 181, 116-124.

Skovgaard Væver, M., Smith-Nielsen, J., \& Lange, T. (2016). Copenhagen infant mental health project: Study protocol for a randomized controlled trial 
comparing Circle of Security-Parenting and care as usual as interventions targeting infant mental health risks. BMC Psychology, 4, 57. https://doi.org/10.1186/s40359-016-0166-8

Squires, C., Lalanne, C., Murday, N., Simoglou, V., \& Vaivre-Douret, L. (2014). The influence of eating disorders on mothers' sensitivity and adaptation during feeding: a longitudinal observational study. BMC pregnancy and childbirth, 14, 274. https://doi.org/10.1186/1471-2393-14-274

Strandjord, S. E., Sabik, J., Nahra, A., Abdulkader, Z., Sieke, E. H., Worley, S., \& Rome, E. S. (2016). Avoidant/Restrictive Food Intake Disorder: Treatment Choice and Outcome in the Outpatient Setting. Journal of Adolescent Health, 58(2), S37S38.

https://doi.org/10.1016/j.jadohealth.2015.10.08 8

Strandjord, S. E., Sieke, E. H., Richmond, M., \& Rome, E. S. (2015). Avoidant/restrictive food intake disorder: Illness and hospital course in patients hospitalized for nutritional insufficiency. Journal of Adolescent Health, 57(6), 673-678. https://doi.org/10.1016/j.jadohealth.2015.08.00 3
Taherdoost, H. (2018). Sampling Methods in Research Methodology; How to Choose a Sampling Technique for Research. SSRN Electronic Journal, (January 2016). https://doi.org/10.2139/ssrn.3205035

Troutman, B. (2015). Integrating behaviorism and attachment theory in parent coaching., xv, 126. https://doi.org/10.1007/978-3-319-15239-4

Uher, R., \& Rutter, M. (2012). Classification of feeding and eating disorders: Review of evidence and proposals for ICD-11. World Psychiatry, 11(2), 80-92.

https://doi.org/10.1016/j.wpsyc.2012.05.005

van der Horst, K., \& Sleddens, E. F. C. (2017). Parenting styles, feeding styles and food-related parenting practices in relation to toddlers' eating styles: A cluster-analytic approach. PloS one, $12(5), \mathrm{e} 0178149$.

Zimmerman, J., \& Fisher, M. (2017). Avoidant/Restrictive Food Intake Disorder (ARFID). Current problems in pediatric and adolescent health care, 47(4), 95-103. 